\title{
Human Rights in the EU Return Policy: The Case of the EU-Albania Relations
}

\author{
Sokol Dedja \\ Doctoral candidate, University of Ghent, Ghent, Belgium
}

\begin{abstract}
The examination of the approach of the EU return policy to Albania - a country to which the EU returns about one fifth of the total number of the third country nationals removed - demonstrates that the predominant focus of the EU return policy on the effectiveness and efficiency of returns has left little room for safeguarding the human rights of the returnees. The article finds that the return procedures of the readmission agreement that should guarantee the protection of human rights in the return process are not observed by the EU member states. There are insufficient guarantees that the reception and possible detention of returnees in Albania will offer a dignified treatment. Moreover, the readmission agreement opens the way for the return of asylum seekers to Albania in line with the 'safe third country' practice in the absence of conditions that ensure effective access to fair and efficient asylum procedures and protection in the country.
\end{abstract}

\section{Keywords}

EU immigration policy; readmission; human rights; Albania; migration

\section{Introduction}

The return of persons illegally residing in the EU has figured prominently in the Community migration policy since its establishment through the Amsterdam Treaty. The Treaty conferred on the Community the power to adopt measures in the area of 'illegal immigration and illegal residence, including repatriation of illegal residents'. ${ }^{1}$ The subsequent development of the EU immigration policy has viewed the removal of irregular migrants and failed asylum seekers as essential for the credibility of a common migration and asylum law and policy. ${ }^{2}$ The main legal instrument for this policy has been the conclusion of readmission agreements with the countries of origin and transit of illegal migrants. When establishing how to implement the provisions introduced by the Amsterdam Treaty the Member States concluded that readmission agreements would constitute a

\footnotetext{
1) Art. 63(3)(b) EC.

2) European Commission, A common policy on illegal immigration, $\operatorname{COM}(2001) 672,15$ November 2001, p. 25.
} 
valuable instrument of an active return policy. ${ }^{3} \mathrm{~A}$ readmission agreement is expected to reduce illegal migration from the concerned country and is considered by the EU as an important element of the development of migration management in the country. ${ }^{4}$ The Tampere European Council in October 1999 invited the Council to start concluding readmission agreements with relevant third countries. ${ }^{5}$ The focus of EU immigration policy on aims such as fighting illegal immigration and securing expulsion and readmission of illegal immigrants entails that the cooperation of the countries of origin and transit is crucial. To secure these countries' cooperation, the Commission referred to a necessary 'complementarity [of EU migration policy] with other Community policies in order to help achieving the Community's objectives in the field of return and readmission'. Return and readmission, the Commission recognized, 'are solely in the interest of the Community, their successful conclusion depends very much on the "leverage" at the Commission's disposal'. 6 To increase the Union's leverage, in cases of 'unjustified lack of cooperation in joint management of migration flows' by a third country, the Union would use the threat of reducing the level of its relations with that country. ${ }^{7}$ More recently, in setting out its priorities in this area for the period 2010-2014 through the Stockholm Programme, the Union confirmed the priority of return and readmission in its external relations ${ }^{8}$ and stressed the need to further develop 'a coherent strategy on readmission [...] taking into account the overall relations with the country concerned, including a common approach towards third countries that do not cooperate in readmitting their own nationals' ${ }^{9}$ Within this context, this article examines - in its second section - the EU approach to secure cooperation in the readmission of irregular migrants originating from or transiting through Albania - a country that has been identified by the EU as a critical factor in the trajectory of irregular migration into the Union. ${ }^{10}$ The second section will also identify the outcomes of the EU policy in the case of Albania in terms of numbers of persons removed. Thus, this analysis will test the expectations of the literature on the external dimension of the EU

\footnotetext{
3) Council of the European Communities and European Commission, Action Plan of the Council and the Commission on how best to implement the provisions of the Treaty of Amsterdam on an area of freedom security and justice, text adopted by the Justice and Home Affairs Council of 3 December 1998, 1999/C 10/01.

4) Schieffer, Martin, 2003. Community Readmission Agreements with Third Countries - Objectives, Substance and Current State of Negotiations, European Journal of Migration and Law 5(3), pp. 343-357.

5) European Council, Presidency Conclusions, Tampere, SN 200/99, 15-16 October 1999.

6) European Commission, Communication from the Commission to the Council and the European Parliament, Integrating migration issues in the EU's relations with third countries, Brussels, COM (2002) final, p. 23.

7) European Council, Presidency Conclusions, Seville, SN 200/1/02 REV 1, 21-22 June 2002.

8) European Council, The Stockholm Programme - An Open and Secure Europe Serving and Protecting Citizens, OJ C 115, 4.5.2010, p. 34.

9) Ibid.

10) EU Council, Presidency Conclusions. Council Meeting. General Affairs, $25-26$ January 1999, Press 21, Nr. 5455/99.
} 
immigration policy, according to which the leverage that pre-accession conditionality confers on the EU allows it to impose adaptation. ${ }^{11}$

The literature on the external impact of the EU immigration policy identifies the negative political consequences of this imposed adaptation for the target countries. But what are the consequences for the human rights of the returnees? Studies on the EU return policy have pointed out that the emphasis on forced return of the EU return measures ${ }^{12}$ has been disproportionate and may seriously undermine the legal safeguards that have traditionally operated in the context of expulsion..$^{13}$ These measures focus on the effectiveness and efficiency of returns at the expense of the human rights of the returnees. The directive defining common standards to be observed in the return process ${ }^{14}$ has been criticized for establishing very vague minimum safeguards and for not reflecting the Council of Europe Guidelines on forced return and EU human rights standards. ${ }^{15}$ In a recent evaluation of EU readmission agreements the Commission itself recognizes the interaction... [of readmission agreements] with human rights and international protection standards' and the existence of 'practical deficiencies which could lead to violations of fundamental rights in the implementation of a readmission procedure'. ${ }^{16}$ Despite the human rights concerns raised by the Commission's evaluation of the readmission agreements the focus on the effectiveness of returns

11) Lavenex, S., and Uçarer Emek, M. (Eds.) (2002). Migration and the Externalities of European Integration. Lanham, MD: Lexington Books; Grabbe, Heather, 2000, 'The Sharp Edges of Europe. Extending Schengen Eastwards, International Affairs 7(3), pp. 519-536; Lavenex, Sandra, 2006, Shifting up and out: The foreign policy of European immigration control, West European Politics, 29(2), pp. 329-350.

12) Council Directive 2001/40/EC of 28 May 2001 on the mutual recognition of decisions on the expulsion of third country nationals OJ L 149/34; Council Dir 2003/110/EC of 25 Nov 2003 on assistance in cases of transit for the purposes of removal by air (2003) OJ L 321/26; Council Dec 2004/573/EC of 29 Apr 2004 on the organization of joint flights for removals from the territory of two or more member states, of third country nationals who are subject of individual removal orders (2004) OJ L 261/28.

13) Cholewinski, R. (2007). The criminalisation of migration in EU law and policy, in: Whose Freedom, Security and Justice? EU Immigration and Asylum Law and Policy, A. Baldaccini, E. Guild and H. Toner (Eds.), Oxford and Portland: Hart Publishing, pp. 301-336; Phuong, C. (2007). Building a Community return policy with third countries: an equal partnership?, in: Baldaccini et al., ibid., pp. 301-336; Bouteillet-Paquet, D., 2003, Passing the Buck: A Critical Analysis of the Readmission Policy Implemented by the European Union and Its Member States, European Journal of Migration and Law 5(3), pp. 359-377.

14) Directive 2008/115/EC of the European Parliament and of the Council of 16 December 2008 on common standards and procedures in Member States for returning illegally staying third-country nationals, OJ L 348, 24 December 2008, p. 98.

15) Phuong, supra note 13, p. 348; UNHCR, UNHCR Position on the Proposal for a Directive on Common Standards and Procedures in Member States for Returning Illegally Staying Third-Country Nationals, 16 June 2008, http://www.unhcr.org/protect. MEPs from the Socialist Group, the Greens and the left, all of whom refused to support the Directive, stated that it breached EU human rights standards, Report on the proposal for a directive of the European Parliament and of the Council on common standards and procedures in Member States for returning illegally staying third-country nationals, A6-0339/2007, European Parliament 20.9.2007.

16) European Commission, Evaluation of EU Readmission Agreements, COM(2011) 76 final, Brussels, 23.2.2011, pp. 10-11. 
remains unchanged. The Stockholm Programme envisages that ' $t$ )he Council should define a renewed, coherent strategy on readmission ${ }^{17}$ on the basis of the Commission evaluation. However, the 'Council conclusions defining the EU strategy on readmission' of June 2011 reiterate the view of the readmission agreements as 'tools of an effective return policy in order to tackle illegal immigration' ${ }^{18}$ and do not mention the human rights concerns and recommendations of the Commission.

The studies mentioned thus far approach the general development of EU return policy and, as a result, do not identify empirically and in a detailed manner the consequences of the EU approach in relation to specific target countries. Studies that deal with EU return policies in relation to specific countries have focused on the effectiveness of such policy and the factors that account for it. ${ }^{19}$ This article approaches the EU return policy in the case of Albania from the viewpoint of the human rights to which the returnees are entitled under international law.

By examining the case of EU policy towards Albania, this article finds that the cooperation of the EU with countries of origin and transit of illegal migrants focuses exclusively on the facilitation of removals of illegal migrants and is not based on a legal framework that identifies and safeguards the rights of the migrants to be removed, especially in relation to the responsibilities of the sending states. The third section of the article will identify a lack of adequate provisions for the protection of human rights in the return process by examining the negotiation and the implementation of the readmission agreement with Albania. The article will subsequently move on to analyze the measures to guarantee the respect of the human rights of the returnees after removal. The fourth section will point to insufficient guarantees that the reception and possible detention of returnees will offer a humane and dignified treatment. The fifth section will find that the burden of reintegration of returnees in Albania is placed on the receiving country with a resulting inadequacy of reintegration measures. Finally, the last section will argue that the readmission agreement opens the way for the return of asylum seekers to Albania according to the 'safe third country' practice without guaranteeing adequate refugee protection in the country.

\footnotetext{
17) European Council, supra note 8, p. 31.

18) 3096th Council meeting, Justice and Home Affairs, Luxembourg, 9 and 10 June 2011, 11008/11, PRESSE 161, PR CO 37, p. 34.

19) Billet, Carole, 2010, EC Readmission Agreements: A Prime Instrument of the External dimension of the EU's Fight against Irregular Immigration, European Journal of Migration and Law, 12(1), pp. 45-79; Trauner, Florian and Kruse, Imke, 2008, EC Visa Facilitation and Readmission Agreements: A New Standard EU Foreign Policy Tool?, European Journal of Migration and Law, 10(4), pp. 411-438. Roig, Annabelle and Huddleston, Thomas, 2007. EC Readmission Agreements: A Re-evaluation of the Political Impasse, European Journal of Migration and Law, 9(3), pp. 363-387. On returns to Albania see Kruse, Imke, 2006, EU Readmission Policy and its Effects on Transit Countries - The Case of Albania, European Journal of Migration and Law 8(2), pp. 115-142.
} 


\section{The Approach of the EU Return Policy to Albania}

Albania is a country from which a total of nearly one million had moved abroad between 1991 and 2005, representing nearly a quarter of the country's total population..$^{20}$ Most of this migration has taken place irregularly with clandestine departures to Italy via the crossing of the Strait of Otranto and to Greece across the mountainous border. ${ }^{21}$ As a result, Albania has a prominent place in the efforts of the EU to curb illegal immigration. In 1999 Albania was identified by an EU High Level Working Group on Asylum and Migration (HLWG) as a critical factor in the trajectory of irregular migration into the EU and therefore selected as a country for which the Union would adopt a 'cross-pillar Action Plan' in order to fight illegal migration into the EU. ${ }^{22}$ The HLWG was set up by the General Affairs Council in December $1998^{23}$ to prepare cross-pillar Action Plans for Afghanistan and the neighbouring region, Morocco, Somalia, Sri Lanka, Iraq, and Albania and the neighbouring region. ${ }^{24}$ These countries were selected on the basis of a comprehensive analysis of flows of asylum seekers and migrants and of the causes of these flows. The Action Plan for Albania provides insights into the concerns of the EU about irregular migration from and through the country. It stresses the country's poverty with 'young people out of work and constituting a large [...] migration potential ${ }^{25}$ and with emigration perceived by large part of the Albanian population 'as the only immediate response to the country's economic needs and social instability'. ${ }^{26}$ Albania is considered a country of origin and a country of transit for Kurds, Indians, Pakistanis and Chinese who reach Italy through Albania. ${ }^{27}$ The report notes the consolidation of the criminal organizations engaged in promoting clandestine immigration with criminal groups that organize and manage the traffic of immigrants to Italy with rubber boats equipped with powerful engines. ${ }^{28}$

Consequently, Albania was one of the 11 countries that were identified as the first group of countries with which the Union would negotiate readmission

\footnotetext{
20) Council of Ministers of the Republic of Albania. 2005. National Strategy on Migration, Government of Albania in cooperation with the International Organisation for Migration, Tirana.

21) For a state of the art on Albanian migration see Vullnetari, Julie (2007). Albanian Migration and Development: State of the art review, IMISCOE Working Paper No. 18.

22) EU Council, Presidency Conclusions. Council Meeting. General Affairs, 25-26 January 1999, Press: 21, Nr. 5455/99.

23) EU Council, Presidency Conclusions. Council Meeting. General Affairs, 6 December 1998, Press: 431, Nr. $13677 / 98$.

24) EU Council, supra note 22.

25) EU Council, High Level Working Group on Asylum and Migration, Draft Action Plan for Albania and the neighbouring region, Council doc.7886/00, 17 April 2000, p. 8.

26) Ibid., p. 13.

27) Ibid., p. 14.

28) Ibid., p. 14.
} 
agreements. ${ }^{29}$ The criteria for the selection of these countries were established by the Justice and Home Affairs Council in April 2002: the migration pressure exerted by the country; its geographical position in relation to the EU; consideration of geographical balance and regional coherence. ${ }^{30}$ The progress in concluding a readmission agreement with Albania was rapid. The agreement was negotiated in three rounds in May, September and November 2003. It was ratified by the European Parliament in early September 2005 and by the Albanian Parliament in January 2006 and entered into force on 1 May 2006. What accounts for the rapid progress in the conclusion of the RA is the leverage conferred on the EU by the pre-accession conditionality. Albania was, among the first group of countries selected for the negotiation of a readmission agreement, the only country with a European accession prospect and thus the only one for which preaccession conditionality was used to obtain cooperation in the readmission of irregular migrants. The control by the EU of the access to each of the stages of the accession process was used as the mechanism for the EU to secure compliance with its readmission-related demands. The European accession prospect was offered explicitly to Albania at the Feira European Council in June 2000 which stated that all the countries of the Western Balkans are 'potential candidates' for EU membership. ${ }^{31}$ The pre-accession process for this region was denominated by the EU as 'Stabilization and Association Process' to emphasize the European perspective as the stabilizer of the region after the wars of the 1990s. The centrepiece of the Stabilisation and Association Process, as defined in the Zagreb Summit in November $2000^{32}$ is the conclusion of a Stabilisation and Association Agreement (SAA). The association established by the SAA is based on the gradual implementation of a free trade area and reforms designed to achieve the adoption of EU standards with the aim of taking the countries closer to EU accession. Thus the SAA is the first important stage in the sequence of steps leading to accession. The formal conditions for the opening of SAA negotiations are related to the country's capacity to take on the obligations of an SAA. However, in the case of Albania, the EU tied the negotiation of the SAA to the negotiation of the readmission agreement. ${ }^{33}$

At a later stage, the conditionality for the liberalization of the EU visa regime for Albanian citizens was used by the EU to compel Albania to adopt a series of measures related to the readmission of irregular migrants and to monitor their

\footnotetext{
29) Schieffer, Martin, 2003, Community Readmission Agreements with Third Countries - Objectives, Substance and Current State of Negotiations, European Journal of Migration and Law 5(3), pp. 343-357.

30) Justice and Home Affairs Council, Presidency Conclusions, Council Doc. 7990/2002 COR 1.

31) European Council, Presidency Conclusions, Santa Maria da Feira, 19-20 June 2000.

32) Zagreb Summit, Final Declaration, 24 November 2000, retrieved from http://ec.europa.eu/ enlargement/enlargement_process.

33) Dedja, S., 2012, The Working of EU Conditionality in the Area of Migration Policy. The Case of Readmission of Irregular Migrants to Albania, East European Politics and Societies 26(1), pp. 115-134.
} 
implementation. The Commission set the benchmarks to be met by Albania in order to advance towards an EU visa free regime in a 'Visa Liberalization Roadmap' presented to the Albanian government on 3 June 2008. ${ }^{34}$ Albania submitted readiness reports and action plans to the Commission, detailing where it stood with each requirement and which measures were adopted to fulfil the requirements. On the basis of these reports and of its field missions the Commission issued a series of assessments on the fulfilment of the requirements of the 'Visa Liberalisation Roadmap'. The measures related to readmission had a prominent place in the visa liberalisation conditionality. The 'Visa Liberalisation Roadmap' establishes that

\begin{abstract}
Albania has to take the necessary measures ensuring effective implementation of the Community Readmission Agreement and in particular, [...] ensuring that proper infrastructure is in place, in particular sufficient staff, to deal with readmission applications, the respect of the various deadlines set by the Community Readmission agreement, the refusals of readmission applications only on the grounds provided by the Community Readmission Agreement, the acceptance of the "EU standard travel document for expulsion purposes", the acceptance of readmission applications for third country nationals/stateless persons. ${ }^{35}$
\end{abstract}

Albania was also required to adopt and implement measures to 'ensure effective expulsion of illegally residing third country nationals from its territory'. ${ }^{36}$ Particular emphasis was also placed on asylum policy: Albania was required to 'adopt and implement legislation [...] in line with international standards (1951 Geneva Convention with New York Protocol) and the EU legal framework and standards' and to 'provide adequate infrastructure and strengthen responsible bodies, in particular in the area of asylum procedures and reception of asylum seekers'. ${ }^{37}$

The leverage conferred on the EU by the pre-accession and visa liberalization conditionality has produced substantial outcomes in terms of numbers of removed persons. The data presented in Table 1 show that removals to Albania account for about one fifth of the total number of the third country nationals removed from the EU. ${ }^{38}$ Thus in the case of Albania the EU aim of effective returns has been fully attained.

34) European Commission, Visa Liberalisation with Albania. Roadmap, Brussels, 2 June 2008.

35) Ibid., p. 3.

36) Ibid., p. 5.

37) Ibid., p. 4.

38) The EU countries remove annually about 300.000 third country nationals, European Commission, Communication from the Commission to the Council and the European Parliament establishing a framework programme on Solidarity and the Management of Migration Flows for the period 2007-2013, COM(2005) 123 final, p. 4. 
Table 1. Number of Persons Returned to Albania From EU Countries by Year ${ }^{39}$

\begin{tabular}{ll}
\hline 2006 & 61884 \\
2007 & 73679 \\
2008 & 66009 \\
2009 & 65484 \\
2010 & 52917 \\
\hline
\end{tabular}

\section{Human Rights in Return Procedures}

The Preamble of the readmission agreement states that the purpose of the agreement is 'to establish rapid and effective procedures for the identification and the safe and orderly return' of persons residing without authorization. ${ }^{40}$ As for the protection of procedural and substantive human rights in the return process, the agreement does establish that it shall be without prejudice to the rights, obligations and responsibilities of the Community, the Member States of the European Union and Albania arising from International Law and, in particular, from the European Convention of 4 November 1950 for the Protection of Human Rights. ${ }^{41}$ However the examination of the negotiations and of the implementation of the readmission agreement ${ }^{42}$ shows that the EU focus on the facilitation of returns has led to a lack of adequate provisions for the protection of human rights in the return process.

During the negotiations for the readmission agreement, Albania tried to negotiate the return procedures but the EU position was that according to Art. 19 of the draft-text these procedural technicalities would be established in bilateral implementation protocols that Albania would conclude with the member states and the EC-Albania readmission agreement would not include such technicalities. The Albanian team consented to defining return technicalities in implementation protocols while accepting all the procedural obligations of the readmission agreement. ${ }^{43}$ Thus Albania accepted that the Albanian nationality or transit

\footnotetext{
39) Report of the State Police of the Republic of Albania to the Fourth meeting of the EU-Albania Joint Readmission Committee, Tirana 24 May 2011. On the Joint Readmission Committees see Note 42.

40) Agreement between the European Community and the Republic of Albania on the Readmission of Persons Residing without Authorisation, OJ L 124, 17.5.2005, p. 22.

41) Ibid.

42) This analysis is based on the minutes of the negotiation rounds for the conclusion of the RA and the minutes of the Joint Readmission Committee. The Joint Readmission Committees has been formally established under the RA as the main tool for monitoring the implementation of the agreement. The committee is co-chaired by the Commission on behalf of the EU, and the third country in question.

43) Council of Ministers of the Republic of Albania, General Comments in the Framework of the Third Round of Negotiations for the Signing of the EC/Albania Readmission Agreement, D. P. M. a. M. o. S. f. E. I., Tirana 2003.
} 
through Albania be established on the basis of prima faci evidence furnished by the authorities of the member states (Arts. 2.1 and 3.1). Prima facie evidence includes documents, certificates and bills of any kind, tickets, and statements by witnesses (Annexes 2 and 3 Readmission Agreement). Albania accepted to reply to readmission applications within a maximum of 14 calendar days (as proposed by the Commission and not 21 days as initially requested by the Albanian side) and that if there was no reply within this time limit, the transfer be deemed to have been agreed to (Art. 10.2 Readmission Agreement). Albania accepted to issue the person whose readmission has been accepted with the travel document required for his or her return within 14 calendar days, or otherwise accept the use of the EU standard travel document for expulsion purposes (Arts. 2.2 and 3.3 Readmission Agreement).

Before the entry into force of the agreement with the EC, readmission of irregular migrants was taking place on the basis of bilateral readmission agreements between Albania and EU member states. Each bilateral agreement was using different forms and contained different articles. Hence a range of implementation procedures and responsible entities and a resulting lack of a clear readmission procedure and of clearly defined institutional structures and responsibilities. In practice, according to the Albanian border officials, Albanian citizens were returned to Albania by relevant authorities in EU member states without prior contact with Albanian authorities. This occurred especially with Italy and Greece. Returns from these countries took place at the border and all procedures were carried out at the respective border points directly and without the involvement of the central structures - Directorate for Migration and Readmission (DMR) of the Albanian State Police. In most cases, Albanian authorities were only informed of the return, once the individual had arrived on the territory of Albania and had been registered by the Border Police. ${ }^{44}$ Thus the official procedures of notification, as outlined in bilateral readmission agreements, were not observed by the EU Member States. ${ }^{45}$

The entry into force of the readmission agreement with the EC should have put an end to this procedural disorder. According to the agreement, when an individual request for readmission has been submitted by the requesting authority to the responsible Albanian readmission entities, readmission can only take place after an official response has been made by the Albanian authorities. This procedure should increase the role of DMR and enable the collection and centralization of data, verification of requests and authorization of readmission procedures. With procedures centralized by DMR, the verification of the identity of the person to be returned should be carried out by the DMR before the return takes place. The DMR should notify the border authorities on future returns.

44) Interviews with DMR officials, May 2009.

45) Ibid. 
When readmissions take place without prior notification, the Albanian returnees are kept at the border until their identity is verified and the police have made sure they are not wanted for criminal acts. This process of verification lasts 8-10 hours with the returnees being kept at the border crossing points. With the entry into force of the readmission agreement with the EC the verification should be carried out preliminarily by the DMR in order to avoid the problem of long verification periods.

However, data from the Albanian Ministry of Interior ${ }^{46}$ demonstrate that the entry into force of the readmission agreement has left the situation unchanged. Of the 66,009 returns in the course of 2008, only 654 were carried out after preliminary notification. The bulk of these returns were from Greece: 63,555 returns in 2008. For none of these the procedure of prior notification was observed. Therefore, in most of the cases, serious humanitarian situations are witnessed at the border with Greece, when dozens of people are sent to Albania without due notice. The situation remained unchanged in 2009: out of around 65,000 readmissions carried out in 2009, only 233 took place upon readmission requests in accordance with the readmission agreement. ${ }^{47}$

The issue of violation of the return procedures was raised by Albania with the Commission in all the yearly meetings of the Joint Readmission Committee. ${ }^{48}$ The Commission undertook to discuss thoroughly that situation with all Member States and suggested that Albania should address the issue with the Members States in bilateral implementing protocols of the readmission agreement. The aforementioned general evaluation of the readmission agreements by the Commission $^{49}$ notes that the reasons given by the member states for non-application of EU readmission agreements are the absence of a bilateral implementing protocol and/or that EU readmission agreements are used only if they facilitate returns. However, the Commission points put that 'the absence of implementing protocols is not an excuse and that the EU readmission agreements are self-standing, directly operational instruments which do not necessarily require the conclusion of bilateral implementing protocols with the third country'.

\footnotetext{
46) Ministry of Interior of the Republic of Albania, Report to the Second Meeting of the EC-Albania Joint Readmission Committee, Brussels, 3 December 2008.

47) Minutes of the Third Meeting of the Joint Committee set up by the Agreement between the European Community and the Republic of Albania on the Readmission of Persons Residing without Authorisation, Tirana, 23 February 2010.

48) Minutes of the Second Meeting of the Joint Committee set up by the Agreement between the European Community and the Republic of Albania on the Readmission of Persons Residing without Authorisation,, Brussels, 3 December 2008. Minutes of the Third Meeting of the Joint Committee set up by the Agreement between the European Community and the Republic of Albania on the Readmission of Persons Residing without Authorisation, Tirana, 23 February 2010.

49) European Commission, Evaluation of EU Readmission Agreements, COM(2011) 76 final, Brussels, 23.2.2011, pp. 10-11.
} 


\section{Reception and Detention of Returnees}

The reception of significant numbers of returnees places a substantial financial burden on the budget of a small and low income country such as Albania. Moreover when evaluating Albania's human rights record the Commission has expressed 'serious concern' in relation to the detention conditions and the treatment of detained persons'..$^{50}$ This means that there are insufficient guarantees that the reception and detention of returnees in Albania will take place in the respect of the human rights of the returnees and offer a humane and dignified treatment.

All the persons returned to Albania are received in border-crossing points where their identity is verified, given that most returns are carried out without prior notification to the Albanian authorities. The Albanian authorities need time to verify the returnee's identity, personal details and criminal record at the border. This can take several hours since, with the exception of large cities, there is a shortage of communication systems. Verification of the returnee's identity can take place in the district where the returnee is registered, and is usually carried out manually. Delays in procedures for identifying returnees lead to their detention in border-crossing points while only a part of the border-crossing are equipped with reception facilities. ${ }^{51}$ As regards the financial resources for the reception of returnees, in 2010 only 120.000 Euros were allocated by the Albanian government for transport from the border-crossing points and basic needs (food and water) of more than 50.000 returnees. ${ }^{52}$

The problem of detention conditions is more serious in relation to third country nationals returned to Albania. As mentioned above, the EU used visa liberalization conditionality to press Albania to adopt and implement measures to 'ensure effective expulsion of illegally residing third country nationals from its territory'. ${ }^{33}$ This approach has resulted in a transfer to Albania of the EU's restrictive immigration policy. To comply with the visa liberalization conditionality Albania adopted the 'Law on Foreigner's, ${ }^{54}$ which sets out the measures for the expulsion of illegally residing third country nationals: an order of expulsion is issued, implying voluntary departure. ${ }^{55}$ In the event of failure to leave voluntarily, within the time period determined in the expulsion order, an expulsion order

\footnotetext{
50) European Commission, Opinion on Albania's application for membership of the European Union, $\operatorname{COM}(2010)$ 680, Brussels, 9.11. 2010.

51) Visa Liberalisation Dialogue, Albania's First Readiness Report, Ministry of Foreign Affairs, Tirana, May 2008.

52) Report of the State Police of the Republic of Albania to the Fourth meeting of the EU-Albania Joint Readmission Committee, Tirana, 24 May 2011.

53) European Commission, Visa Liberalisation with Albania. Roadmap, Brussels, 2 June 2008, p. 5.

54) Law no 9959 of 17.07.2008.

55) In the period September 2010-April 2011, 207 Leaving Orders have been issued for 118 Palestinian citizens, 15 Afghans, 13 Somalis, 8 Tunisian, 7 Turkish, 6 from Morocco and 4 Sudanese. Report of the State Police of the Republic of Albania to the Fourth meeting of the EU-Albania Joint Readmission Committee, Tirana, 24 May 2011.
} 
through coercion is issued. The individual shall be detained in a 'closed centre' until the expulsion order is enforced; this period can last up to 6 months and can be extended for 6 other months. The Regulation for the functioning of the Centre for the detention of illegal immigrants was adopted in the period of the visa liberalization dialogue with the $\mathrm{EU}^{56}$ and the construction of the centre completed in November 2009 with a reception capacity of 200 persons. $^{57}$

While detention in the centre is meant as e temporary measure, the difficulties faced by Albania in removing third country nationals to their countries of origin ${ }^{58}$ lead to long detention periods and a resulting increase of the number of detainees with serious consequences for their detention conditions, given the limited capacity of the detention centre. The very low numbers of removals - 9 in 2006, 36 in 2007, 93 in 2008,,$^{59} 42$ in 2009, and 29 in $2010^{60}$ - is related to difficulties in obtaining the cooperation of the countries of origin. This is hardly surprising given the difficulties of the EU itself to conclude readmission agreements with countries of origin of irregular immigrants. ${ }^{61}$ There is hardly anything Albania can offer these countries in return for the signature of a readmission agreement. Moreover, to date Albania has not made any budget allocation for the removal of irregular migrants. ${ }^{62}$ One episode illustrates the consequences of these difficulties for immigrants kept in detention centres: in 2007 a group of Indian nationals, despite their wish to return as quickly as possible, expressed even by hunger strike, were detained for months. Their escape from an improvised reception centre and the following action of the Ministry of Interior for capturing them was the consequence of a long detention in poor conditions. ${ }^{63}$

The evaluation of Albania's difficulties in dealing with returned third country nationals is related to the potential caseload. The third country national clause of the readmission agreement entered into force in May 2008. Since its entry into force it has rarely been used by the EU member states. ${ }^{64}$ However, it is difficult to draw any conclusions on the future potential caseload. Representatives of EU

\footnotetext{
56) Decision of the Council of Ministers of the Republic of Albania No. 1083, of 28 October 2009, Official Journal of the Republic of Albania, Nr. 165, 2009, p. 7287, Tirana, 4 December 2009.

57) Visa Liberalisation Dialogue, Albania's Readiness Report, Ministry of Foreign Affairs, Tirana, November 2009. Prior to the construction of the detention centre irregular migrants were detained in centre for victims of trafficking.

58) Kruse, supra note 19.

59) European Commission, Updated Assessment of the implementation by Albania of the Roadmap for Visa Liberalisation, 18 May 2009.

60) Report of the State Police of the Republic of Albania to the Fourth meeting of the EU-Albania Joint Readmission Committee, Tirana, 24 May 2011.

61) Schieffer, supra note 29.

62) Visa Liberalisation Dialogue, Albania's First Readiness Report, Ministry of Foreign Affairs, Tirana, May 2008.

63) Bushati, D. (2008). Albania Roadmap on Visa Liberalization, European Movement Albania Report, $15-10$

64) European Commission, Evaluation of EU Readmission Agreements, COM(2011) 76 final, Brussels, 23.2.2011.
} 
member states have encouraged their Albanian counterparts by suggesting that they are more likely to return third country nationals to their country of origin, rather than to Albania as a country of transit. ${ }^{65}$ However, it has been acknowledged by EU experts that, where individuals cannot be returned to their country of origin, third country nationals will be sent to Albania, if it can be proved that they have transited through Albania. ${ }^{66}$ It may prove easier and more cost-effective to send irregular third country nationals to Albania than to their country of origin and nothing in the readmission agreement prevents EU member states from doing so. Returns are difficult to predict also because they depend on the capacity of the EU member states to capture and detain irregular immigrants and on the political decisions on returning them.

In conclusion, the transfer of the restrictive EU policy on irregular migration combined with the difficulties of a low-income country for which the EU itself has expressed concerns in relation to the detention conditions results in a lack of safeguards for the respect of the human rights of the returnees in relation to the reception and detention conditions.

\section{Reintegration of Returnees}

Returns are sustainable only if support for the economic and social integration of the returnees is provided. The Commission communication on the return policy ${ }^{67}$ recognizes the importance of the EU support for the reintegration of the returnees through integration return programs that involve reception upon arrival, follow-up assistance and counselling after the return. However, return programs funded by the EU can prove very expensive as it has been demonstrated for instance by the case of the Afghanistan return plan. ${ }^{68}$ In the case of the Western Balkan countries, the EU used visa liberalization conditionality to place the burden of reintegration of returnees entirely on the receiving countries. ${ }^{69}$ The Commission assessment of the fulfilment by Albania of visa liberalization conditionality in May 2009 demands a 'more proactive approach' in relation to the reintegration of returnees. In a later assessment in May 2010 the Commission concluded that Albania had met all but a few outstanding benchmarks for visa liberalization and proposed to transfer Albania from the negative to the positive list, 'it being understood that by the day of adoption of the proposal by the European Parliament and the Council, [Albania] should fulfil all benchmarks'.

\footnotetext{
65) Interviews with DMR officials, May 2009.

66) IOM, Return and Readmission. The Case of Albania, International Organization for Migration, August 2006.

67) European Commission, A Community return policy on illegal residents, COM(2002)564, 14 October 2002, p. 21.

68) Phuong, supra note 13, pp. 301-336.

69) On the lack of reintegration assistance by the EU for Albanian returnees, see Kruse, supra note 19.
} 
Thus, the pressure was very high for the fulfilment of these outstanding benchmarks. One of those was 'the development of a strategy and policy to support the reintegration of Albanian returnees'. ${ }^{70}$ The Commission pointed that

given the very significant number of returnees, it is of utmost importance to swiftly adopt a comprehensive strategy and policy including concrete operational measures to facilitate sustainable return and reintegration. This should [...] involve all relevant state agencies, in particular the National Employment Service [and include] measures on broadening reintegration services. ${ }^{71}$

In compliance with the Commission requests, a study on reintegration was carried out by the Albanian authorities in $2009^{72}$ and led to the adoption of the 'Strategy on Reintegration of Returned Albanian Citizens'. ${ }^{73}$ The strategy applies to all returnees (including voluntary), though its particular focus is on Albanian citizens readmitted under the EU-Albania readmission agreement. The strategy identifies the needs faced by the returnees, such as registration, housing, education and employment. The Action Plan for the implementation of the Strategy sets out 41 specific measures relating to the legislative framework (revision of legislation in all relevant policy areas by the end of 2010), capacity-building (establishment of 36 'migration counters' at local and regional offices of the National Employment Service, and designation of reintegration contact points in line ministries and the Border and Migration Police) as well as provision of information and assistance to foster the reintegration of returnees (e.g. guidance on opportunities and assistance available to returnees and referral to relevant agencies or NGOs). The monitoring of the Strategy's implementation is to be ensured by a high-level inter-ministerial committee reporting to the Prime Minister, on the basis of biannual reports prepared by the Directorate of Migration Policy, Return and Reintegration within the Ministry of Labour, Social Affairs and Equal Opportunities.

Although the Commission considered the strategy as a 'comprehensive mechanism for the promotion of returnee reintegration covering the main reintegration needs faced by returnees, ${ }^{74}$ a closer look at the strategy itself and the examination of the first implementation outcomes reveals a rather different picture. The Strat-

\footnotetext{
70) European Commission, Proposal for a Regulation of the European Parliament and of the Council of the European Union amending Regulation (EC) No 539/2001 listing the third countries whose nationals must be in possession of visas when crossing the external borders of Member States and those whose nationals are exempt

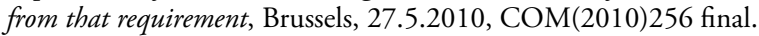

71) European Commission, Updated Assessment of the implementation by Albania of the roadmap for visa liberalization, 6 May 2010.

72) Visa Liberalisation Dialogue, Albania's Second Readiness Report, Ministry of Foreign Affairs, Tirana, October 2009.

73) Adopted by the Council of Ministers with Decision No. 461, on 9 June 2010, Official Journal of the Republic of Albania, Nr. 95, p. 5063, Tirana, 23 July 2010.

74) European Commission, Commission Staff Working Document on the fulfillment of the open benchmarks by Albania and Bosnia and Herzegovina in the framework of the Commission Proposal for a Council Regulation amending Regulation (EC) No 539/2001 listing the third countries whose nationals must be in possession
} 
egy makes it clear that 'reintegration support' should consist mainly of improving information made available to returned Albanian citizens on existing social services accessible to all Albanian citizens under the Albanian legal framework, rather than providing them with extra services. ${ }^{75}$ Information on social services would be provided at border crossing points and regional and local employment offices where 'migration counters' are established for this purpose. The migration counters were originally established to provide information on possibilities for regular emigration as a project financed by AENEAS Program 2006 of the EU. ${ }^{76}$ The pressure from the EU to provide for the reintegration of returnees induced Albania to add to the tasks of the migration counters the provision of information on social services to returnees and the compilation of a register of returned Albanian migrants. The number of Albanian returnees registered through this service -544 returnees in $2010^{77}$ - is insignificant compared to the number of returns in the same year $-52,917$. This demonstrates clearly the very limited impact of the new reintegration measures. The financial resources dedicated by the Albanian authorities to the implementation of the reintegration measures are also very limited: the budget of 120.000 Euro allocated by the Albanian government for the implementation of the reintegration strategy in 2010 was mainly spent to provide food and water upon return at the border-crossing points and transport. $^{78}$

Thus, placing the burden of reintegration of returnees solely on the receiving country results in insufficient reintegration support. The consequent reintegration difficulties faced by the returnees compel them to attempt to re-enter the EU irregularly. The official data of the Albanian Ministry of Interior register this phenomenon: in 2009, 64625 returns to Albania were effectuated but they involved 47239 Albanian citizens, ${ }^{79}$ as a considerable number of persons were returned more than once.

\section{Refugee Protection}

The development of the external dimension of the EU asylum policy has aimed to contain refugees in their regions of origin or in transit countries, thus 'external-

\footnotetext{
of visas when crossing the external borders and those whose nationals are exempt from that requirement, Brussels, 14.09.2010, SEC(2010) 1085 final.

75) Republic of Albania, Strategy on Reintegration of Returned Albanian citizens, 2010-2015, Official Journal of the Republic of Albania, Nr. 95, Tirana, 23 July 2010, p. 5063.

76) Visa Liberalisation Dialogue, Albania's First Readiness Report, Ministry of Foreign Affairs, Tirana, May 2008.

77) Republic of Albania, Information to the Stabilisation and Association Committee, Ministry for European Integration, Tirana, 16.3.2011.

78) Report of the State Police of the Republic of Albania to the Fourth meeting of the EU-Albania Joint Readmission Committee, Tirana, 24 May 2011.

79) Supra note 75, p. 5063.
} 
ising responsibility for asylum seekers' ${ }^{80}$ The Commission has clearly indicated that the returns to third countries could target 'third country nationals for whom the third country has been or could have been a country of first asylum, if this country offers effective protection' ${ }^{81}$ In this attempt to shift the onus of refugee protection to third countries, the most widespread common practices are those based on the 'safe third country' concept. ${ }^{82}$ The concept is defined in EU law by the 'Directive on minimum standards on procedures in Member States for granting and withdrawing refugee status' ${ }^{83}$ The directive establishes that a country can be considered to be a first country of asylum for a particular applicant for asylum if he/she otherwise enjoys sufficient protection in that country, including benefiting from the principle of non-refoulement, provided that he/she will be re-admitted to that country. ${ }^{84}$ The EU Member states can return an applicant for asylum to the first country of asylum if the latter is considered a 'safe third country'. The application of the safe third country concept is subject to rules laid down in national legislation of member states which may take into account the criteria defined in the directive. These include the possibility to request refugee status and, if found to be a refugee, to receive protection in accordance with the Geneva Convention. ${ }^{85}$ The readmission agreements are a necessary condition to make possible the returns of applicants for asylum to third countries. However, the need to ensure that countries to which applicants for asylum may be returned satisfy the safety criteria has prompted the Union to aim also at enhancing refugee protection in a number of third countries. ${ }^{86}$ Whereas for instance in the Western Newly Independent States (Ukraine, Moldova, Belarus) the Union developed Regional Protection Programmes to enhance protection capacity, in the case of the Western Balkan countries the EU used the visa liberalization conditionality to ensure that the countries develop adequate protection standards for refugees.

\footnotetext{
80) Baldaccini, A. (2007). The external dimension of the EU's asylum and immigration policies, in: A. Baldaccini, E. Guild and H. Toner (Eds.), Whose Freedom, Security and Justice? EU Immigration and Asylum Law and Policy, (Oxford and Portland: Hart Publishing), pp. 277-298.

${ }^{81)}$ European Commission, Communication on the managed entry into the EU of persons in need of international protection and the enhancement of the protection capacity of the regions of origin: 'Improving access to durable solutions, COM(2004)410 final, 4 June 2004, para 51.

${ }^{82}$ C Costello, C. (2007). The asylum procedures directive in legal context: equivocal standards meet general principles, in: Baldaccini et al. (Eds.), supra note 80, pp. 151-194.

83) 'Council Directive 2005/85/EC of 1 December 2005 on minimum standards on procedures in Member States for granting and withdrawing refugee status', OJ L 326/13, 13.12.2005.

84) Ibid., Art. 26.

85) Ibid., Art. 27.

86) European Commission, Commission Communication to the Council and the European Parliament of 1 September 2005 on regional protection programmes, $\operatorname{COM(2005)} 388$ final. This approach was recently confirmed in the Stockholm Programme which stressed the need to further develop 'approaches concerning access to asylum procedures targeting main countries of transit' and to 'to enhance capacity building in third countries, in particular, their capacity to provide effective protection, and to further develop and expand the idea of Regional Protection Programmes', European Council, The Stockholm Programme, supra note 8 , p. 33 .
} 
In the case of Albania, since May 2008 the readmission agreement has created the possibility to return third country nationals. However, at the time of the entry into force of the third country national clause the Commission evaluations showed that Albania could not be considered a safe third country. In 2007 the Commission estimated that 'no coherent single asylum strategy is yet in place'. The Commission stressed the need to review the legal framework on asylum and noted that 'Albania's protection regime for those granted asylum remains weak, especially its judicial aspects'. In the 2007 Commission assessment, the need for Albania to enhance its protection capacity is clearly linked to the EU return policy as the Commission stresses that the impact of readmission agreements on asylum system capacity has not yet been properly evaluated' and that 'Albania continues to be a transit country for asylum-seekers'. ${ }^{87}$

Subsequently, the EU used the Visa Liberalization Dialogue that started the following year to increase pressure on Albania to enhance its protection capacity. The asylum-related conditionality of the visa liberalisation negotiations aimed to make the country 'safe' for returns. Albania was required to

adopt and implement legislation [...] in line with international standards (1951 Geneva Convention with New York Protocol) and the EU legal framework and standards' [and to] 'provide adequate infrastructure and strengthen responsible bodies, in particular in the area of asylum procedures and reception of asylum seekers. ${ }^{88}$

As a precondition for visa liberalization Albania reviewed in January 2009 its law on asylum ${ }^{89}$ to bring it into line with the 1951 Convention Relating to the Status of Refugees, the 1967 Protocol Relating to the Status of Refugees, as well as the EU Directive on Qualification for Refugee Protection and Subsidiary Status. ${ }^{90}$ As requested by the EU, ${ }^{11}$ the new law also establishes the procedural rules on examination of applications for international protection in line with the EU Directive on Asylum Procedures. ${ }^{92}$ To implement the preconditions for visa liberalisation, Albania also adopted the provisions defining the rights granted to asylum seekers taking into account the EU Directive on Reception Conditions for Asylum Seekers, ${ }^{93}$ including inter alia family reunification, access to education, access to the labour market, health service, housing. ${ }^{94}$ Indeed the Commission communication on the enhancement of refugee protection capacity in third countries

87) European Commission, Albania 2007 Progress Report, COM(2007) 663 final, p. 44.

88) European Commission, Visa Liberalisation with Albania. Roadmap. Brussels. 2 June 2008, p. 4.

89) Law Nr. 10060, of 26.1.2009, retrieved from: http://qpz.gov.al/doc.jsp?doc=docs/Ligj\%20 Nr\%20 10060\%20Dat\%C3\%AB\%2026-01-2009.htm

90) Directive 2004/83/EC (2004), OJ L 304/12.

91) European Commission, Visa Liberalisation with Albania. Roadmap, Brussels, 2 June 2008.

92) Directive 2005/85/EC (2005), OJ L 326/13.

93) Directive 2003/9/EC (2003), OJ L 31/18.

94) Visa Liberalisation Dialogue, Albania's First Readiness Report, Ministry of Foreign Affairs, Tirana, May 2008. 
suggests that suitable indicators to assess the protection capacity of a host country and whether a sustainable protection system has developed should be drawn from the elements the EU uses itself when guaranteeing refugee protection. ${ }^{95}$

According to the asylum procedures established in Albania by the new legislation, the 'Department for citizenship and refugees' in the Ministry of Interior processes and accepts requests for asylum and implements measures concerning protection and assistance to refugees. Hitherto, although the number of asylum applications is very low, the Department has been unable to carry out the procedure of application and hearing within the 51 days legal time limit due to insufficient staff. ${ }^{96}$ Therefore the new asylum law of 2009 extended this legal time limit to 71 days. Before the entry into force of the 2009 law, complaints against the decisions of the Department for citizenship and refugees were examined by a National Commission for Refugees - a body consisting of 8 members appointed by 8 central institutions. In 2009 the National Commission for Refugees was dismissed because of serious deficiencies in its functioning, which resulted in a significant backlog in the treatment of applications. In line with the EU recommendation the new law replaces the administrative complaints with judicial appeals: a negative decision on asylum is directly appealed to the First Instance Court.

The creation of the reception conditions in Albania was a task performed by the UNHCR until 2009. In the context of the Visa Liberalization Dialogue the Commission put pressure on Albania to take over the tasks performed by the UNHCR in this area and monitored closely the implementing measures required for ensuring the effective access of asylum seekers and persons recognized as in need of international protection to the rights foreseen by the 2009 law. ${ }^{97}$ Thus Albania adopted a series of implementing measures ${ }^{98}$ that, according to the Commission evaluation, allow Albania to take ownership of the integration of refugees by taking over the tasks performed in this area by UNHCR. ${ }^{99}$ The final Commission report of the visa liberalization process concluded that 'Albania's

\footnotetext{
95) European Commission, Communication on the managed entry into the EU of persons in need of international protection and the enhancement of the protection capacity of the regions of origin: 'Improving access to durable solutions', COM(2004)410 final, 4 June 2004, para 43.

96) Visa Liberalisation Dialogue, Albania's First Readiness Report, Ministry of Foreign Affairs, Tirana, May 2008.

97) European Commission, Updated Assessment of the implementation by Albania of the roadmap for visa liberalization, Brussels, 27 November 2009.

98) Council of Ministers Decision Nr. 1102, of 4.11.2009 'On health services for persons to whom asylum is granted and for persons who have applied for asylum in the Republic of Albania', Official Journal of the Republic of Albania, Nr 173, p. 7685, Tirana, 16 December 2009. Instruction of the Minister of Education and Science no. 32, date 26.10.2009 'On the registration and evaluation of students to whom asylum is granted in the Republic of Albania'.

99) Supra note 97.
} 
asylum system is functional and the legislative framework has been further strengthened to ensure alignment with international and EU standards'. ${ }^{100}$

The positive evaluation of the Commission in conclusion of the Visa Liberalization Dialogue could potentially open the way for the inclusion of Albania in the 'safe third country' practice by the EU member states - a practice sanctioned by the EU Asylum Procedures Directive. ${ }^{101}$ However, in reality Albania has established procedural guarantees but nor well-resourced asylum infrastructures ensuring effective access of asylum seekers to the protection that the legislation provides. The new legislation is very recent and not tested with a significant number of applicants. The Albanian human and financial resources and infrastructures are able to cope only with the current low caseload. As at the end of 2010, there were 76 recognized refugees and 23 asylum applicants. ${ }^{102}$ With its 5 employees the Directorate for Citizenship and Refugees has the capacity to deal adequately only with this very low caseload. ${ }^{103}$ The National centre for reception of asylum seekers has a reception capacity of 200 persons and 15 employees. A part of the bordercrossing points are not yet equipped with reception facilities. ${ }^{104}$ In addition, the decrease of the financial support by the UNCHR and the shift of the financial burden on the state budget ${ }^{105}$ means that the country is ill-prepared for an increased caseload that would result from returns of asylum seekers from EU member states on the basis of 'third safe country' practice.

In summary, although the readmission agreement mentions obligations arising from the ECHR and the 1951 Refugee Convention and its 1967 Protocol, ${ }^{106}$ it opens the way for the return of asylum seekers to Albania according to the 'safe third country' practice without guaranteeing that they are effectively granted access to fair and efficient asylum procedures and protection in Albania.

\footnotetext{
100) European Commission, Updated Assessment of the implementation by Albania of the roadmap for visa liberalization, Brussels 6 May 2010.

101) In some EU member states the list of countries with whom they have entered into readmission agreements is used for the application of the safe third country principle, European Commission, The Law and Practice on Safe Country Principles Against the Background of the Common European Asylum System and the Goal of a Common Asylum Procedure, DG JAI-A2/2002/04, p. 59.

102) UNHCR, Global trends 2010, retrieved from http://www.unhcr.org/4dfa11499.html.

103) European Commission, Updated Assessment of the implementation by Albania of the roadmap for visa liberalization, Brussels 6 May 2010.

104) Visa Liberalisation Dialogue, Albania's First Readiness Report, Ministry of Foreign Affairs, Tirana, May 2008.

105) In 2008, 21,116 million ALL were allocated by the State budget for asylum seekers and refugees while donation by UNHCR was 5 million ALL. . However the allocation from the state budget is still not sufficient. For instance, asylum-seekers legal representatives are still supported through the UNHCR budget. Albania's First Readiness Report, Visa Liberalisation Dialogue. Ministry of Foreign Affairs, Tirana, May 2008.

106) Agreement between the European Community and the Republic of Albania on the Readmission of Persons Residing without Authorisation, OJ L 124, 17.5.2005, p. 22.
} 


\section{Conclusion}

The examination of the case of a country to which the EU returns about one fifth of the total number of the removed third country nationals demonstrates that the predominant focus of the EU return policy on the effectiveness and efficiency of returns has left little room for safeguarding the human rights of the returnees. The leverage conferred on the EU by the pre-accession and visa liberalization conditionality greatly facilitates returns. In the case of Albania the outcomes in terms of numbers of persons removed are substantial. Thus my analysis confirms the expectations of the literature on the external dimension of the EU immigration policy, according to which the leverage that pre-accession conditionality confers on the EU allows it to impose adaptation. However, this dictated adaptation also creates the conditions for the disproportionate concern of the Union with the numbers of returns to overshadow the issue of the human rights of the returnees. As a result of the EU leverage, Albania is extremely cooperative in the readmission of migrants originating from or transiting through the country although its preparedness for such a move is deficient. In such a situation, the protection of the human rights of the returnees is seriously put at risk. The guarantees that the detention of returnees in Albania will take place in the respect of the human rights of the returnees and offer a humane and dignified treatment are insufficient. Moreover, the readmission agreement opens the way for the return of asylum seekers to Albania according to the 'safe third country' practice without guaranteeing that they are effectively granted access to fair and efficient asylum procedures and protection in Albania. The burden of creating minimum conditions for the reintegration of the returnees is also placed on the receiving country which results in insufficient reintegration measures.

Furthermore, Albania's responsiveness to the demands of the EU and its member states goes beyond the obligations of the readmission agreement. The EU's position of power limits Albania's possibility to demand the observation of the readmission agreement by the EU member states. Thus a substantial number of returns to Albania take place despite the fact that EU member states do not observe the return procedures of the readmission agreement that should guarantee the protection of the human rights in the return process. In these conditions of a weak position of the receiving country towards the EU member states, there is room for the Commission to play its role of guardian of EU law by taking legal steps in cases of violation by the member states of the return procedures established by the readmission agreements. 